\title{
Alkaline Phosphatase Activity of Marsilea crenata Presl. Extract and Fractions as Marker of MC3T3-E1 Osteoblast Cell Differentiation
}

\author{
Burhan Ma'arif ${ }^{*}$, Mangestuti Agil², Hening Laswati ${ }^{3}$ \\ ${ }^{1}$ Departement of Pharmacy, Faculty of Medical and Health Sciences, Universitas Islam Negeri Maulana Malik Ibrahim, Malang, Indonesia. \\ ${ }^{2}$ Departement of Pharmacognosy and Phytochemistry, Faculty of Pharmacy, Universitas Airlangga, Surabaya, Indonesia. \\ ${ }^{3}$ Departement of Physical Medicine and Rehabilitation, Faculty of Medicine, Universitas Airlangga, Surabaya, Indonesia.
}

\begin{tabular}{|c|c|}
\hline ARTICLE INFO & ABSTRACT \\
\hline $\begin{array}{l}\text { Article history: } \\
\text { Received on: } 16 / 08 / 2017 \\
\text { Accepted on: } 17 / 10 / 2017 \\
\text { Available online: } 30 / 03 / 2018\end{array}$ & $\begin{array}{l}\text { Phytoestrogen is a group compound which has estrogen-like structure or function. The aim of this research was to } \\
\text { evaluate phytoestrogen stimulating activity inside Marsilea crenata Presl leaves on alkaline phosphatase (ALP), a } \\
\text { marker in osteoblast differentiation. Osteoblast cells were exposed with } n \text {-hexane extract of } M \text {. crenata leaves with } \\
\text { dose } 400,200,100,50 \text {, and } 25 \mathrm{ppm} \text {, and } 4 \text { fractions of } M \text {. crenata leaves with dose } 25 \mathrm{ppm} \text { for } 48 \text { hours. } N \text {-hexane } \\
\text { extract and four fractions of } M \text {. crenata leaves were tested using immunocytochemistry (ICC) and confocal laser }\end{array}$ \\
\hline $\begin{array}{l}\text { Key words: } \\
\text { Marsilea crenata } \text { Presl., } \\
\text { MC3T3-E1, alkaline } \\
\text { phosphatase, phytoestrogens. }\end{array}$ & $\begin{array}{l}\text { scanning microscopy (CLSM). The results showed anon monotonic response was between dose improvement of } \\
n \text {-hexane extract and ALP activity, whereas fraction } 2 \text { and fraction } 4 \text { were able to increase ALP activity that valued of } \\
96.711 \text { and } 131.840 \text {, respectively, which was more than control. Through correlation analysis between research result } \\
\text { and literature, it could be concluded that palmitic acid in fraction } 2 \text { and fraction } 4 \text { were phytoestrogen compound in } M \text {. } \\
\text { crenata that played role in the improvement of ALP activity in MC3T3-E1 osteoblast cell. }\end{array}$ \\
\hline
\end{tabular}

\section{INTRODUCTION}

Osteoporosis is a condition which is characterized by decreasing of bone mass that is accompanied by destruction of bone micro-architecture and leads to increase the risk of fracture (Villiers, 2009; Lee et al., 2013). A rapid rate of bone resorption that exceeds the rate of bone formation results in bone abnormalities such as osteoporosis (Tung et al., 2009). Osteoblast cell plays a crucial role in bone formation through the proliferation and differentiation. Thus, stimulation of osteoblast differentiation has been suggested to be an important therapeutic approach for the prevention and treatment of osteoporosis (Tung et al., 2009; Widyowati, 2011).

Osteoblast differentiation is a complex process of sequential expression of marker proteins such as alkaline phosphate (ALP) (Widyowati, 2011). ALP is one of the important markers in the process of cell differentiation. It is formed in the early stage

"Corresponding Author

Burhan Ma'arif, Departement of Pharmacy, Faculty of Medical and Health Sciences, Universitas Islam Negeri Maulana Malik Ibrahim, Malang Indonesia.E-mail: burhan.maarif@farmasi.uin-malang.ac.id of differentiation of the pre-osteoblast cell into osteoblast and acts as a promoter of matrix formation and mineralization (Golub and Battaglia, 2007; Kini and Nandeesh, 2012).

Marsilea crenata Presl is a unique plant that grows in East Java, Indonesia. Its leaves are widely used as ingredients for traditional food (Afriastini, 2003; Nurjanah et al., 2012). The aim of this research is to determine whether $M$. crenata has the potential effect to increase ALP activity in MC3T3-E1 osteoblast cell. Several studies have been conducted and showed that ethanol extract of the leaves of $M$. crenata could prevent osteoporosis in postmenopausal women through improvement of bone formation (Yacoeb et al., 2010; Laswati, 2011).

The anti-osteoporosis activity in the plant was occurred due to the phytoestrogen compounds in M. crenata. Phytoestrogens were a group of compounds derived from plants that had estrogenlike structures or could replace the function of estrogen in its bond with estrogen receptors (Cos et al., 2003; Ososki and Kennelly, 2003; Villiers, 2009; Yang et al., 2012). To know its activity, $M$. crenata leaves were extracted with $n$-hexane then being separated into four fractions group. It had an effect on proliferation and differentiation process of the MC3T3-E1osteoblast cell. It was 
studied with ICC method and the measurement of ALP activity was conducted by CLSM instruments.

\section{MATERIAL AND METHODS}

\section{Plants material}

M. crenata were collected in Benowo district, Surabaya, Indonesia in September 2015, and was identified in UPT Materia Medica, Batu, Indonesia at September 2015 with specimen number 1a-17b-18a-1. The leaves were dried and ground in order to retain their green color.

\section{Materials}

Fetal bovine serum (FBS), alpha modification of eagles medium ( $\alpha$ MEM), dimethyl sulfoxide (DMSO), secondary ALP antibody, penicillin, streptomycin, and other reagents were purchased from Central Laboratory of Living Science, Brawijaya University, Malang, Indonesia. Polyclonal Anti-ALPL Antibody was purchased from Boster Biological Technology Co., Ltd., USA.

\section{Cell culture}

MC3T3-E1 osteoblast cell strain C57BL/6 Subclone 4 (ATCC $^{\circledR}$ CRL2593 $^{\text {TM }}$ ) were purchased from American Type Culture Collection, Manassas, USA. MC3T3-E1osteoblast cell cultured in 24-well microplate in $\alpha \mathrm{MEM}$ contained $10 \% \mathrm{FBS}, 1 \%$ L-glutamine, $1 \%$ natrium pyruvate, $100 \mathrm{U} / \mathrm{ml}$ penicillin, and 100 $\mathrm{U} / \mathrm{ml}$ streptomycin in a $5 \% \mathrm{CO}_{2}$ incubator at $37^{\circ} \mathrm{C}$. Each of them contained $5 \times 10^{4}$ cells in $4.5 \mathrm{ml}$ medium, and $50 \mu 1$ ascorbic acid to induce the proliferation process. All were incubated for 6 days.

\section{Extraction and separation procedure}

The extraction of $1.5 \mathrm{~kg} M$. crenata leaves was performed by maceration for $4 \times 24$ hours at $27^{\circ} \mathrm{C}$ using $24 \mathrm{~L} n$-hexane solvent. For separation with vacuum column chromatography, the $n$-hexane extract was dried with silica gel 60 Merck (70-230 Mesh) of the same amount. The vacuum column preparation was first performed by compressing the silica gel $60 \mathrm{G}$ Merck in the chromatographic column with a diameter of $6.5 \mathrm{~cm}$ and height 6.5 $\mathrm{cm}$ which was connected to the vacuum pump. The eluent used was $n$-hexane and ethyl acetate with gradient elution.

\section{Preparation of test samples}

The $n$-hexane extract, fraction 1 , fraction 2 , fraction 3 , and fraction 4 (50 mg each) were mixed with $0.5 \%$ Tween, and 80 and $50 \mathrm{ml}$ of DMSO $0.5 \%$ which then was vigorously shaken at room temperature to produce $1000 \mathrm{ppm}$ sample solution. Each sample was filtered using $0.22 \mu \mathrm{l}$ Millipore. The $1000 \mathrm{ppm}$ $n$-hexane extract was diluted to produce 400, 200, 100, 50, and $25 \mathrm{ppm}$ final concentration. The $1000 \mathrm{ppm}$ fraction 1 , fraction 2, fraction 3 , and fraction 4 were also diluted to produce $25 \mathrm{ppm}$ final concentration. The samples solution ( $n$-hexane extract and fractions) then were added to a 24 -well microplate containing MC3T3-E1 osteoblast cell for 48 hours.

After the medium was disposed from 24-well microplate, cells were fixed with PFA 4\% for 15 minutes. Then, it was rinsed well with PBS in five minutes in a shaker. Discarding the PBS, then adding blocking buffer (5\% FBS in PBS) of $300 \mathrm{ml}$ and waiting for 20 minutes in a shaker. After that, it was rinsed well in 5 minutes with PBS for three times. Later, discarding the PBS, adding the primary antibody (anti-rabbit ALP) of $300 \mathrm{ml} /$ well, and waiting for 1 hour. Later, it was rinsed well with PBS for $3 \times 5$ minutes in a shaker. Then, Discarding the PBS, adding a secondary antibody (anti-rabbit FITC) of $300 \mathrm{ml} /$ well and keeping for 45 minutes in darkness and being wrapped in aluminum foil. Then, it was rinsed well with PBS for $3 \times 5$ minutes and we observed ALP fluorescence with CLSM at $488 \mathrm{~nm}$-wavelengths (Widyowati, 2011).

\section{RESULTS AND DISCUSSIONS}

\section{ALP activity of $\boldsymbol{n}$-hexane extract}

The ALP fluorescence in MC3T3-E1 osteoblast cell before being given the sample solution is described in Figure 1, while the ALP fluorescence in an MC3T3-E1osteoblast cell after being given the sample solution is described in Figure 2.

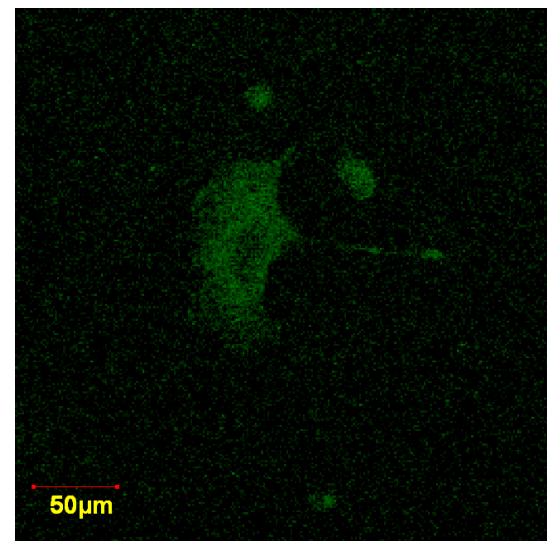

Fig. 1: MC3T3-E1 osteoblast cell before being given the sample solution.

In Figure 1 and Figure 2, well-grown and healthy cells are characterized by well-attached and static appearance, the cells also polygonal, not shrinking or swelling. ALP activity then is calculated based on the intensity of ALP fluorescence. The value of ALP activity in cells after administration of $n$-hexane extract of $M$. crenata leaves in different dose is described in Table 1 and Figure 3.

Table 1: The value of ALP activity in cells after administration of $n$-hexane extract of $M$. crenata leaves in different dose.

\begin{tabular}{cc}
\hline Dose & ALPActivity \\
\hline Negative Control & 353.950 \\
$25 \mathrm{ppm}$ & 904.206 \\
$50 \mathrm{ppm}$ & 430.054 \\
$100 \mathrm{ppm}$ & 488.347 \\
$200 \mathrm{ppm}$ & 514.570 \\
$400 \mathrm{ppm}$ & 1282.512 \\
\hline
\end{tabular}

Table 1 and Figure 3 show the relation which is not linear between given dose and ALP activity (response). Increasing dose is not accompanied by improvement of ALP activity in cells. This shows the effect of nonmonotonic response on MC3T3-E1 
osteoblast cell after being given the $n$-hexane extract of $M$. crenata leaves (Vandenberg et al., 2012). Nonmonotonic response characteristics are indicated by the slope values that vary at some points within the given dose range. The nonmonotonic response often occurs in the study with hormone or hormone replacement treatment as samples. In this case, phytoestrogen compound is inside $n$-hexane extract of $M$. crenata leaves. This is because the study with this kind of samples tends to use small dose but with erratic effects. The difference in the degree of affinity between a hormone or a hormone replacement sample with a receptor on both target receptor and non-target receptor in cells will cause difficulties in predicting the response that will arise with increasing dose. It is also difficult to determine the dose of therapy and toxic dose for compounds that have nonmonotonic response properties, because if the compound is declared safe at high dose, it is not necessarily safe at a low dose, and vice versa.

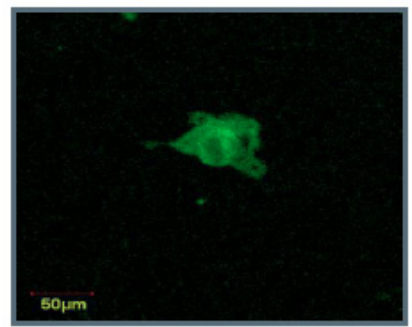

a

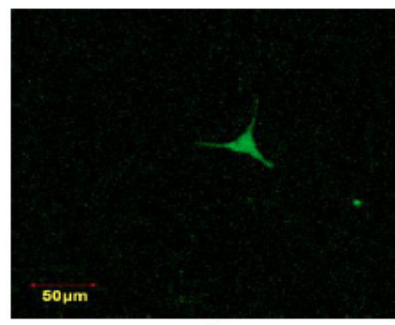

d

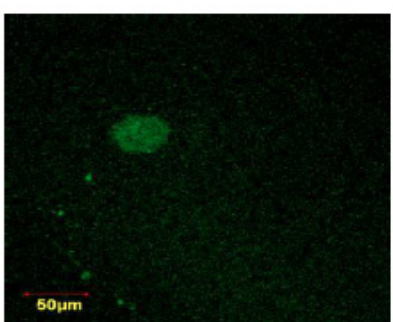

b

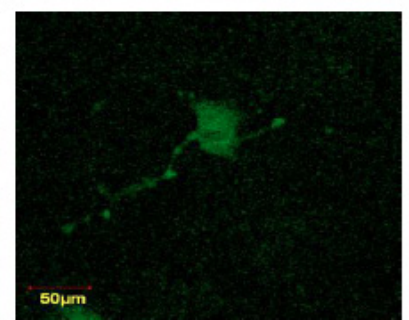

c

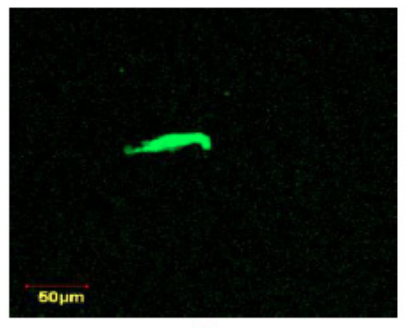

Fig. 2: The ALP fluorescence in MC3T3-E1osteoblast cell after being given the sample solution: (a) 25 ppm; (b) 50 ppm; (c) 100 ppm; (d) 200 ppm; and (e) 400 ppm.

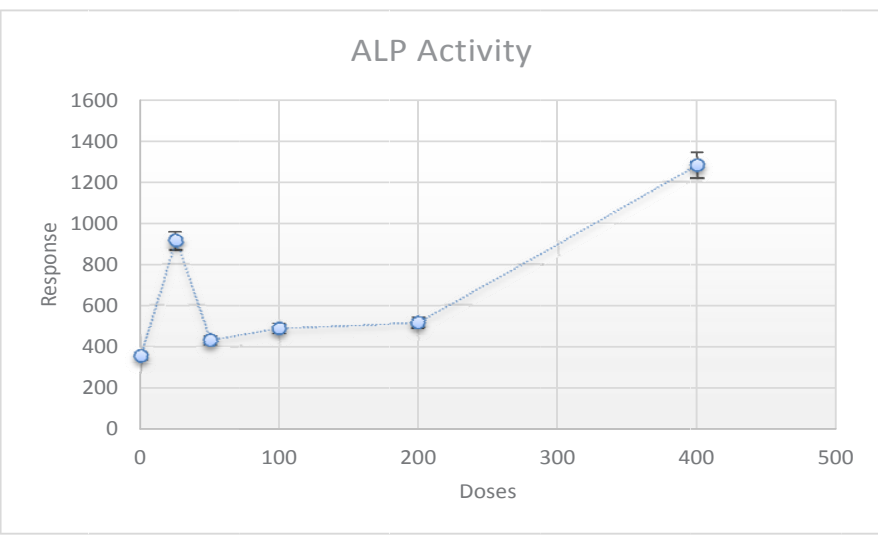

Fig. 3: The value of ALP activity in cells after administration of $n$-hexane extract of $M$. crenata leaves in different dose.

The nonmonotonic response of phytoestrogen compounds of $n$-hexane extract of $M$. crenata can is caused by several things. First, it is because of selectivity of the receptor. The nonmonotonic response can occur due to the difference in affinity and receptor selectivity to the compounds, which in this case is the difference in the affinity and selectivity of receptors in osteoblast cell to the low-dose and high-dose of $n$-hexane extracts from $M$. crenata leaves. At a low dose of phytoestrogens in $n$-hexane extract will bind exclusively to estrogen receptor $\beta(\mathrm{ER} \beta)$ with a large affinity, resulting in a large activity response as well. However, with a higher dose, phytoestrogens in $n$-hexane extract are likely to bind to other receptors other than $\operatorname{ER} \beta$ that also present in the osteoblast cell, which in turn leads to decreasing response activity resulting from the antagonistic effects between two different receptors (Moriyama et al., 2002). At the higher dose, it is possible that phytoestrogens will bind several receptors at once, such as $\mathrm{ER} \beta, \mathrm{ER} \alpha$, thyroid hormone receptors, and other receptors. This increase in the number of receptors tied to these varied allowed affinities for increasing response activity (Moriyama et al., 2002; Tilghman et al., 2010).

The second is because of receptor down-regulation mechanism. In the interaction process, after the bonding between phytoestrogens in $n$-hexane extract of $M$. crenata leaves and ER $\beta$, it will produce transcription factors of cell differentiation process such as osterix (Osx) and runt-related transcription factor-2 (Runx-2). These transcription factors will then induce a series of processes at the DNA level to produce ALP and induction of differentiation of osteoblast cell. At the same time, an increase in the number of administered dose will also cause the compounds to bind to other receptors. The bond will also produce other transcription factors. The transcription factors which are generated by the bonding of these other receptors can lead to inactivation and degradation of ER $\beta$ via proteasome pathways, resulting in a down-regulation receptor with the decreasing of activity response (Ismail and Nawaz, 2005). Based on sources of some research journals, it is known that a transcription factor generated from the bonding of receptors can indeed activate and degrade other types of receptors. In this case, there is inactivation of ER $\beta$ due to the presence of other high dose receptor bonds and ultimately 
leads to a decrease in the activity response of ER $\beta$. On the other hand, at a certain stage where the addition of this dose continues to be increased, the amount of degraded ER $\beta$ will increase and ultimately not proportional to the amount of ER $\beta$ production. This will then cause the cell to produce ER $\beta$ massively resulting in an increase in the bonding of the ER $\beta$ - compound and the response activity (Modrall et al., 2001).

Another possibility that can occur due to the increased dose of the $n$-hexane extract of $M$. crenata given is desensitization of the receptor. At low dose phytoestrogens in the extract can bind exclusively with $\operatorname{ER} \beta$ that resulting in a large response activity. However, with the addition of dose, it can trigger the occurrence of desensitization of ER $\beta$ which causes decreasing response activity. Desensitization of ER $\beta$ may occur due to constant exposure to compounds with high dose, thus making ER $\beta$ insensitive in binding to phytoestrogens in $n$-hexane extracts (Lohse, 1993; Freedman and Lefkowitz, 1996). Another possibility that may occur is that at some stages the dose increases continuously, the amount of descending ER $\beta$ will increase, and it leads to degradation. This increase in degradation is ultimately not proportional to the amount of ER $\beta$ production, thus causing the cell to produce ER $\beta$ massively as a consequence. This will increase the bond between phytoestrogens with ER $\beta$ which resulting in the increasing response activity (Modrall et al., 2001).

The last possibility that can occur is the downstream mechanism. The expression profile of a gene in a cell may differ between treatments at a low dose and high dose. The advent of nonmonotonic response effects on the suggested results there may be a small number of genes in cells that have higher sensitivity to low dose when compared with a high dose. In this study, in the provision of low dose $n$-hexane extracts, a gene with high sensitivity is thought to be a gene that regulates cell apoptosis and genes that regulate cell differentiation, so that low dose will inhibit the process of cell apoptosis while enhancing the differentiation process. Genes that have high sensitivity to this particular dose rate may differ depending on the type of cell and type of compound (usually hormone or hormone replacement). In addition, a mechanism that explains how the sensitivity of this gene can occur due to induction of various dose of the compound is still unknown. So, there is the possibility of giving a higher dose than before which can lead to sensitivity to other genes in the cell. Also, leading to increased differentiation process and response activity (Vendenberg et al., 2012).

\section{ALP activity of fractions}

Fractions were given $25 \mathrm{mg}$ dose for each. The ALP activities of fraction 1 until 4 are described in Table 2.

ALP activity test with fractions as samples was similar to previous $n$-hexane extracts. The $25 \mathrm{ppm}$ dose of fractions is chosen by two considerations. First, it was based on an explanation of the nonmonotonic response effect. ER $\beta$ has a greater likelihood to bind exclusively and produce an optimal response when binding to compounds at low dose than a high dose. The second consideration was from several research journals. They mentioned that the dose used in MC3T3-E1 osteoblast cell type for ALP activity test was about 1-50 ppm (Choi et al., 2001; Chen et al., 2011; Widyowati, 2011).
Table 2: The ALP activities of fraction 1 until 4 of M. crenata leaves.

\begin{tabular}{cc}
\hline Sample & ALP Activity \\
\hline Negative Control & 73.942 \\
Fraction 1 & 53.667 \\
Fraction 2 & 96.711 \\
Fraction 3 & 56.355 \\
Fraction 4 & 131.840 \\
\hline
\end{tabular}

The results of ALP activity of fractions showed that not all fractions can increase the ALP activity. Fraction 2 and fraction 4 could increase the ALP activity, whereas fraction 1 and fraction 3 were actually ALP activities which were under negative control. These showed that fraction 2 and fraction 4 might contain compounds that played a role in inducing ALP production, whereas in fraction 1 and fraction 3 had not contained such compound. Based on previous research, the major compound that was found in fractions 2 and 4 was palmitic acid, whereas in fraction 1 there was no palmitic and in fraction 3 there was a low concentration of palmitic acid content (Ma'arif et al., 2016).

From these data, it was known that palmitic acid was a compound that acted as phytoestrogens and induced the production of ALP in osteoblast cells. In some studies, it was found that administration of free fatty acids such as palmitic acid might increase the differentiation of mesenchymal stem cells (MSC) into osteoblasts in in vitro assays, and also increase bone mineral density (BMD) of mice in in vivo tests by histomorphometric bone analysis (Shan et al., 2010; Kim et al., 2013). The mechanism of palmitic acid in enhancing the osteogenesis process occurred through significantly increasing transcription factors of differentiation processes such as Runx2 and Osx. Improvement of transcription factor would be followed by a series of molecular reactions and ended by the occurrence of differentiation of preosteoblast cells with osteoblasts which was characterized by increasing production of ALP and osteocalcin (Shan et al., 2010, Kim et al., 2013).

\section{CONCLUSION}

The $n$-hexane extract, fraction 2 and fraction 4 of $M$. crenata leaves can increase bone formation through induction of MC3T3-E1 osteoblast cells in differentiation process which is gotten from increasing ALP activity through measurement of ALP fluorescence intensity with CLSM. Phytoestrogen group compounds that play a role in enhancing bone formation through the induction of MC3T3-E1 osteoblast cells in differentiation process is palmitic acid.

\section{ACKNOWLEDGMENT}

This research was supported by Central Laboratory of Living Science, Brawijaya University, Malang, Indonesia.

\section{REFERENCES}

Lee WL, Tsui K, Seow KM, Cheng MH, Su WH, Chen CP, Wang $\mathrm{PH}$. Hormone therapy for postmenopausal women and unanswered issue. Elsevier: Gynecology and Minimally Invasive Therapy, 2013; 2:13-17.

Villiers TJ. Bone health and osteoporosis in postmenopausal women. Elsevier: Best Practice \& Research Clinical Obstetrics and Gynaecology, 2009; 23:73-85. 
Tung NH, Ding Y, Choi EM, Minh CV, Kim YH. New Neolignan Component from Camellia amplexicaulis and Effects on Osteoblast Differentiation. Chemical Pharmacy Bull, 2009; 1:65-68.

Widyowati R. Alkaline Phosphatase Activity of Graptophylum pictum and Sphilanthes acmella Fractions Against MC3T3-E1 Cells as Marker of Osteoblast Differentiation Cells. International Journal of Pharmacy and Pharmaceutical Sciences, 2011; 3. Suppl 1.

Golub EE and Battaglia KB. The role of alkaline phosphatase in mineralization. Current Opinion in Orthopaedics, 2007; 19:444-448.

Kini U and Nandeesh BN. Physiology of Bone Formation, Remodeling, and Metabolism. Springer: Radionuclide and Hybrid Bone Imaging, 2012.

Nurjanah, Azka A, Abdullah A. Aktivitas Antioksidan dan Komponen Bioaktif Semanggi Air (Marsilea crenata). Jurnal Inovasi dan Kewirausahaan, 2012; 1 (3):152-158.

Afriastini JJ. 2003. Marsilea crenata Presl. Di dalam: de Winter WP, Amoroso VB, editor. Cryptograms: Ferns and fern allies. Bogor: LIPI.

Laswati H. Green Clover Potentiates Delaying the Increment of Imbalance Bone Remodeling Process in Postmenopausal Women. Folia Medica Indonesiana, 2011; 47(2):112-117.

Yacoeb AM, Nurjanah, Arifin M, Sulistiono W, Kristiono SS. Deskripsi histologis dan perubahan komposisi kimia daun dan tangkai semanggi (Marsilea crenata Presl., Marsileaceae) akibat perebusan. Jurnal Pengolahan Hasil Perikanan Indonesia XII, 2010; 2:81-95.

Cos P, Bruyne TD, Apers S, Berghe DV, Pieters L, Vlietinck AJ. A Review: Phytoestrogen Recent Developments, 2003.

Ososki AL and Kennelly EJ. Phytoestrogens: a Review of the Present State of Research. Phytotherapy Research, 2003; 17:845-869.

Yang TS, Wang SY, Yang YC, Su CH, Lee FK, Chen SC, Tseng CY, Jou HJ, Huang JP, Huang KE. Effects of standardized phytoestrogen on Taiwanese menopausal women. Elsevier: Taiwanese Journal of Obstetrics \& Gynecology, 2012; 51:229-235.

Ma'arif B, Agil, M, Laswati H. 2016. Phytochemical assessment on $n$-hexane extract and fractions of Marsilea crenata Presl. leaves through GC-MS. Trad. Med. J, 2016; 21(2):77-85.

Vandenberg LN, Colborn T, Hayes TB, Heindel JJ, Jacobs DR, Lee DH, Shioda T, Soto AM, Saal FS, Welshons WV, Zoeller RT, Myers JP. Review: Hormones and Endocrine-Disrupting Chemicals: Low-Dose Effects and Nonmonotonic Dose Responses. Endocrine Journal, 2012; 33. No 3.

Tilghman SL, Nierth-Simpson EN, Wallace R, Burow ME, McLachlan JA. Environmental hormones: Multiple pathways for response may lead to multiple disease outcomes. Steroids, 2010; 75:520-523.

Moriyama K, Tagami T, Akamizu T, Usui T, Saijo M, Kanamoto N, Hataya Y, Shimatsu A, Kuzuya H, Nakao K.Thyroid hormone action is disrupted by bisphenol A as an antagonist. J Clin Endocrinol Metab, 2002; 87:5185-5190.

Modrall JG, Nanamori M, Sadoshima J, Barnhart DC, Stanley JC, Neubig RR. ANGII type 1 receptor downregulation does not require receptor endocytosis or G protein coupling. Am J Physiol Cell Physiol, 2001; 281:C801-C809.

Ismail A, Nawaz Z. Nuclear hormone receptor degradation and gene transcription: an update. IUBMB Life, 2005; 57:483-490.

Freedman NJ, Lefkowitz RJ. Desensitization of G proteincoupled receptors. Recent Prog Horm Res, 1996; 51:319-351.

Lohse MJ. Molecular mechanisms of membrane receptor desensitization. Biochim Biophys Acta, 1993; 1179:171-188.

Chen L, Lei L, Ding P, Tang Q, Wu Y. Osteogenic effect of Drynariae rhizoma extracts and Naringin on MC3T3-E1 cells and an induced rat alveolar bone resorption model. Elsevier: Archives of oral biology, 2011; 56:1655-1662.

Choi EM. Liquiritigenin isolated from Glycyrrhiza uralensis stimulates osteoblast function in osteoblastic MC3T3-E1 cells. Elsevier: International Immunopharmacology, 2012; 12:139-143.

Kim J, Park Y, Lee S, Park Y. Trans-10, cis-12 Conjugated linoleic acid promotes bone formation by inhibiting adipogenesis by peroxisome proliferator activated receptor- $\gamma$-dependent mechanisms and by directly enhancing osteoblastogenesis from bone marrow mesenchymal stem cells. Elsevier: Journal of Nutritional Biochemistry, 2013; 24:627-679.

Shan, Wu L, Cheng P, Yu J, Zhang A, Zha J, Liu J, Wang L, Di W, Hu M, Qi H, Li Y, Ding G. Correlation of obesity and osteoporosis: Effect of free fatty acids on bone marrow-derived mesenchymal stem cell differentiation. Experimental and therapeutic medicine, 2010; 1:603-610.

\section{How to cite this article:}

Ma'arif B, Agil M, Laswati H. Alkaline Phosphatase Activity of Marsilea crenata Presl. Extract and Fractions as Marker of MC3T3-E1 Osteoblast Cell Differentiation. J App Pharm Sci, 2018; 8(03): 55-59. 